\title{
Awareness of the risk factors of stroke among non-teaching staff of the Nnamdi Azikiwe University, Nnewi Campus, Anambra State, Nigeria
}

\author{
Uchenna Prosper Okonkwo ${ }^{1 *}$ (D, Favour Nnenna Uzuh', Maduaburochukwu Joseph Nwankwo', \\ Emmanuel Chiebuka Okoye' , Joseph Onuwa Ummuna', Emeka Sylvester Igwe'2, Stanley Monday Maduagwu', \\ Kenneth Umezulike Ani ${ }^{1}$, Uzoamaka Nwakaego Akobundu ${ }^{1}$ and Chiamaka Ann Nwanne ${ }^{1}$
}

\begin{abstract}
Background: The prevalence of stroke is increasing in Nigeria due to a lack of awareness of their predisposing factors. There is therefore a need for good knowledge and awareness of stroke risk factors in the general populations. Thus, this study assessed the level of awareness of stroke risk factors among non-teaching staff in Nnamdi Azikiwe University, Nnewi Campus, Nigeria.

Results: Most of the participants were female, 89 (69\%), and had a post-graduate degree, 84 (65.1\%). A total of 129 participants participated in this survey, and 91 (70.5\%) were familiar with the term "stroke."The commonest risk factors were high blood pressure (86\%), stress (74.4\%), and lack of exercise (63.6\%). The study showed that the awareness of stroke risk factors among the participants was poor (40.3\%).

Conclusion: Stroke awareness was poor among the participants with the highest risk of stroke despite their high literacy level. Female participants, with a postgraduate level qualification and working as senior non-teaching staff, had a better awareness of stroke risk factors than their male colleagues. This shows a need to increase stroke awareness campaigns in the community.
\end{abstract}

Keywords: Awareness, Stroke, Risk factors, Non-teaching staff

\section{Background}

Stroke, known medically as cerebrovascular accident (CVA), is defined as the interruption of blood to the brain, that is due to blockage of a blood vessel in the brain or rupture of a blood vessel, causing bleeding in the brain or into the spaces surrounding the brain [1]. A stroke occurs when there is a sudden death of some brain cells due to a lack of oxygen when the blood flow to the brain

\footnotetext{
*Correspondence: up.okonkwo@unizik.edu.ng

${ }^{1}$ Department of Medical Rehabilitation, Faculty of Health Sciences

and Technology, Nnamdi Azikiwe University, Awka, Nigeria

Full list of author information is available at the end of the article
}

is lost by blockage or rupture of an artery to the brain. It is a leading cause of dementia and depression [2].

The primary pathophysiology of stroke is an underlying heart or blood vessel disease, while the primary pathologies include hypertension, atherosclerosis leading to coronary artery disease, dyslipidemia, heart disease, and hyperlipidemia [3].

Stroke is an important health determinant especially in Africa where these events were historically reported to be rare probably as a result of a lack of resources to conduct proper community-based studies to assess its burden [2]. Africa appears to have the highest incidence, prevalence, and case fatality of stroke [4-6]. 
Nigeria is the most populous black nation in the world with a population of 140 million people, and its stroke prevalence rate was reported as 1.14 per 1000 with a higher prevalence of 1.51 per 1000 in males compared to 0.69 per 1000 in females [7]. Most studies of stroke in Nigeria were hospital-based, and available data indicates that stroke accounts for $0.23-4 \%$ of hospital admissions, $0.5-45 \%$ of neurological admissions, and $5-17 \%$ of medical deaths. Data from hospital-based studies shows that the 30-day case fatality rate from stroke is high and ranges from 28 to $40 \%$, with those with complications having worse outcomes $[8,9]$. Furthermore, the reported average age of stroke patients seen in Nigerian hospitals ranged between 57 and 64 years [10-13].

Many of the established risk factors for stroke, including hypertension, high cholesterol, diabetes, heart disease, and smoking, can be prevented and controlled either through healthier lifestyle choices or by medication. There are modifiable and non-modifiable stroke risks, and proper management of some of these risks could significantly reduce the risk of stroke incidence [14]. Akinyemi [13] noted that $90 \%$ of the burden of stroke globally is attributed to modifiable risk factors.

However, Alkadry et al. [14] proffer that the proper management of the risk of stroke requires public awareness of these risks and awareness of appropriate approaches to manage them [15]. In the same vein, Al Shafaee et al. [15] think that the knowledge of the risk factors of stroke might improve primary prevention through lifestyle modification and more efficient control of cardiovascular risk factors [16].

Despite numerous efforts of the scientific world on stroke, it remains one of the leading causes of death globally and is a major cause of disability worldwide [17]. Consequently, there is an important need for good knowledge and awareness of stroke risk factors among the general population. Most studies on the knowledge of risk factors of stroke were done on the general public, university students, stroke survivors, and hypertensive patients, but there are no recent studies on non-teaching staff as members of the university community based on the awareness of risk factors of stroke.

The aforementioned limitation notwithstanding the previous study has reported that respondents in older age groups and having lower levels of educational attainment tended to have less knowledge of risk factors and warning signs of stroke [18]. It was also found in another study that out of 2283 non-teaching staff of the University of Ibadan, only about $200(8.8 \%)$ non-teaching staff attended federal universities [19]. Their study learned credence to the fact that the population of nonteaching staff members of the Nigerian universities is characterized by a high proportion of lower levels of educational attainment.

Therefore, the essence and imperativeness of this research study are highlighted by Hickey et al. [20] when she opined that a greater understanding of perceived risk factors and warning signs for stroke would facilitate health interventions aimed at reducing morbidity and mortality from stroke. Thus, the study aims to assess the level of awareness of the risk factors of stroke among non-teaching staff members of the Nnamdi Azikiwe University.

\section{Methods \\ Study design}

This was a cross-sectional survey design.

\section{Study population}

The population for this study comprises non-teaching staff in the Nnamdi Azikiwe University, Anambra state.

\section{Inclusion and exclusion criteria}

Non-teaching staff members who are working at the Nnamdi Azikiwe University, Nnewi Campus, Anambra state and gave consent were eligible for this study. At the same time, those who did not give consent and did not complete the questionnaire were excluded from this study.

\section{Sample size}

The sampling size was estimated using the G-power statistical software package version 3.1.10. A sample size of 200 has $95 \%$ power to detect a medium effect size of 0.3 .

An alpha level of 0.05 was used.

\section{Sampling technique}

A convenience sampling technique was used for recruitment. A total of 200 questionnaires were distributed, but 129 individuals consented to participate in the study.

\section{Study instrument}

The Modified Version of Kamran's Questionnaire (2007) on awareness of stroke risk factors was adapted, modified, and applied in evaluating the level of awareness of stroke risk factors among the participants in the current study [21]. The questionnaire was validated by three research experts in a Nigerian university before being administered (content validity). The modified version of the questionnaire is a 20-item closed-ended questionnaire with two sections: section A-socio-demographic characteristics which include age, gender, marital status, highest educational level status, and non-teaching staff position; section $\mathrm{B}$-which accesses the awareness of stroke risk factors questionnaire. The questions inquire 
about the awareness of stroke, the risk factors, causes, symptoms, and their required source of information on stroke.

\section{Data collection procedure}

The researchers trained two research assistants who assisted in questionnaire distribution and collation. They were given a 3-day training ( $3 \mathrm{~h}$ per day) to ensure they understand the intricacies involved in questionnaire administration. The researchers were concerned with the explanation of the content of the questionnaire to the consenting participants, ensuring proper filling of the questionnaire, and obtaining consent from the participants. The 20-item questionnaire was designed to take a maximum of $7 \mathrm{~min}$ to complete. The respondents were either given the questionnaire to answer by themselves or aided to answer by the researchers in cases where they could not do so, especially for those with low-level education. The completed questionnaires were collated at the point of completing them by the research assistants to minimize the attrition rate. The researchers extracted the information on the participants' demographics and awareness of the risk factors of stroke from the completed questionnaires using an Excel spreadsheet. The data collated were then subjected to analysis.

\section{Data analysis}

Descriptive statistics of frequency counts and percentages were used to summarize the data while Pearson chisquare was used to analyze the correlation between the level of awareness of stroke risk factors and some selected demographics. The data were analyzed using the Statistical Package for Social Sciences (SPSS) by IBM, version 26. The alpha level was set at 0.05 .

\section{Results}

Out of 129 participants, the females accounted for most of the research participants at $89(69 \%)$ while the males were $40(31 \%)$. Their mean age was $40.29 \pm 10.31$ (Table 1). Most of the participants are married with postgraduate education. The senior non-teaching staff constituted most of the participants.

The majority of the participants $(70.5 \%)$ recognized the term stroke, saw it as a disorder primarily affecting the brain (52.7\%), and thought that young people can suffer a stroke (54.3\%). About $92.2 \%$ of the participants thought that a person can reduce the risks of stroke, $70.5 \%$ of the participants thought the risk of stroke was high in $>50$ years old age groups, and $39.5 \%$ of the participants thought the risk of stroke was equal in both males and females (Table 2).
Table 1 Socio-demographics characteristics of the respondents

\begin{tabular}{lll}
\hline $\boldsymbol{N = 1 2 9 , \text { demographics }}$ & Category & Frequency, $\boldsymbol{n}$ (\%) \\
\hline Gender & Male & $40(31)$ \\
Age & Female & $89(69)$ \\
& $18-30$ & $21(16.3)$ \\
& $31-40$ & $47(36.4)$ \\
& $41-50$ & $37(28.7)$ \\
& $51-60$ & $22(17.1)$ \\
Mean age & $>60$ & $2(1.6)$ \\
Marital status & $40.29 \pm 10.31$ & \\
& Single & $35(27.1)$ \\
& Married & $89(69)$ \\
& Separated & $1(0.8)$ \\
& Widowed & $4(3.1)$ \\
Educational level status & None & $1(0.8)$ \\
& Primary school & $2(1.6)$ \\
& Secondary school & $13(10.1)$ \\
& Undergraduate & $26(20.2)$ \\
& PGD/M.Sc. & $84(65.1)$ \\
Non-teaching & PhD & $3(2.3)$ \\
& Junior staff & $21(16.3)$ \\
& Senior staff & $108(83.7)$ \\
\hline
\end{tabular}

Table 2 Participants'awareness of stroke

\begin{tabular}{|c|c|c|}
\hline$N=129$, variables & Category & Frequency, $n(\%)$ \\
\hline \multirow[t]{2}{*}{ Recognise the term stroke } & Yes & $91(70.5)$ \\
\hline & No & $38(39.5)$ \\
\hline \multirow[t]{6}{*}{ Stroke is a disorder affecting } & Brain & $68(52.7)$ \\
\hline & Blood sugar & $4(3.1)$ \\
\hline & Blood pressure & $26(20.2)$ \\
\hline & Heart & $13(10.1)$ \\
\hline & Stomach & $1(0.8)$ \\
\hline & Do not know & $17(13.2)$ \\
\hline \multirow[t]{4}{*}{ The risk of stroke } & Higher in males & $34(26.4)$ \\
\hline & Higher in females & $16(12.4)$ \\
\hline & Equal in both & $51(39.5)$ \\
\hline & Do not know & $28(21.7)$ \\
\hline \multirow[t]{4}{*}{ Age groups with a high risk } & $<30$ years old & $4(3.1)$ \\
\hline & 30-50 years old & $19(14.7)$ \\
\hline & $>50$ years old & $91(70.5)$ \\
\hline & Do not know & $15(11.6)$ \\
\hline \multirow[t]{3}{*}{ Can young people suffer it } & Yes & $70(51.3)$ \\
\hline & No & $41(31.8)$ \\
\hline & Do not know & $18(14)$ \\
\hline \multirow[t]{3}{*}{ Can a person reduce the risks } & Yes & $119(92.2)$ \\
\hline & No & $2(1.6)$ \\
\hline & Do not know & $8(6.2)$ \\
\hline
\end{tabular}


Table 3 Distribution rank of awareness of stroke risk factors among the participants

\begin{tabular}{llll}
\hline $\begin{array}{l}\boldsymbol{N}=1 \mathbf{1 2 9}, \\
\text { parameters }\end{array}$ & $\begin{array}{l}\text { Knowledge } \\
\text { category }\end{array}$ & Frequency, $\boldsymbol{n}$ & Percentage (\%) \\
\hline Risk factors & Poor (0-9) & 52 & 40.3 \\
& Fair (10-12) & 40 & 31 \\
& Good (13-19) & 37 & 28.7 \\
\hline
\end{tabular}

Table 4 Participant awareness of the individual risk factors of stroke

\begin{tabular}{lll}
\hline $\boldsymbol{N}=\mathbf{1 2 9}$, risk factors of stroke & Correct, $\boldsymbol{n}$ (\%) & Incorrect, $\boldsymbol{n}$ (\%) \\
\hline High blood pressure & $111(86)$ & $18(14)$ \\
Cigarette smoking & $67(51.9)$ & $62(48.1)$ \\
Diabetes mellitus & $53(41.1)$ & $76(58.9)$ \\
High cholesterol level & $70(54.3)$ & $59(45.7)$ \\
Obesity & $68(52.7)$ & $61(47.3)$ \\
Stress & $96(74.4)$ & $33(25.6)$ \\
Lack of exercise & $82(63.6)$ & $47(36.4)$ \\
Alcohol consumption & $68(52.7)$ & $61(47.3)$ \\
Sickle cell anemia & $18(14)$ & $111(86)$ \\
Coronary heart disease & $64(49.6)$ & $65(50.4)$ \\
Atrial fibrillation & $36(27.9)$ & $93(72.1)$ \\
\hline
\end{tabular}

Table 5 Association between awareness of stroke risk factors and the demographics of respondents

\begin{tabular}{lll}
\hline $\boldsymbol{N}=\mathbf{1 2 9}$, demographics & $\boldsymbol{X}^{\mathbf{2}}$ & $\boldsymbol{P}$ value \\
\hline Gender & 3.697 & 0.158 \\
Education & 11.518 & 0.319 \\
Age & 10.584 & 0.226 \\
Marital status & 4.219 & 0.647 \\
Non-teaching staff & 3.624 & 0.163 \\
\hline
\end{tabular}

The results show that the percentage of respondents with poor awareness (40.3\%) of stroke risk factors was more than those with good awareness (28.7\%) (Table 3).

High blood pressure (86\%), stress (74.4\%), and lack of exercise $(63.6 \%)$ were most frequently identified as risk factors of stroke while sickle cell anemia (14\%) and atrial fibrillation (27.9\%) were the least identified risk factors of stroke (Table 4).

There was no significant association between the level of awareness of stroke risk factors and the participants' gender, marital status, age, educational level, and nonteaching staff position. Individuals who were females, with a postgraduate level of education and working as senior non-teaching staff, had better awareness of stroke risk factors (Table 5).
Table 6 Preferred source of information by respondents

\begin{tabular}{lll}
\hline $\boldsymbol{N = 1 2 9}$, source of information & Frequency, $\boldsymbol{n}$ & Percentage (\%) \\
\hline Family member & 2 & 1.6 \\
Books & 15 & 11.6 \\
Health staff, doctors, and nurses & 99 & 76.7 \\
Health education material, posters, & 31 & 24 \\
and brochures & & \\
TV and radio & 10 & 7.8 \\
Newspaper and magazine & 7 & 5.4 \\
\hline
\end{tabular}

The most preferred source of information on stroke was health officials, doctors, nurses (76.7\%), health education materials, posters, brochures (24\%), and books (11.6\%) while TV and radio (7.8\%), newspaper and magazines (5.4), and family members (1.6\%) were least preferred sources of information (Table 6).

\section{Discussion}

Socio-demographics characteristics of the participants

This study investigated the level of awareness of the stroke risk factors among non-teaching staff working at the Nnamdi Azikiwe University. There were more female respondents $(69 \%)$ than male respondents $(31 \%)$, as this was in line with several studies which had also investigated knowledge of stroke risk factors which had more female respondents than male respondents [22-25].. Another factor that could explain the higher number of females in the current study was that in the Nigerian civil service structure, there is a significant preponderance of females in comparison with their male counterparts; men prefer going into business ventures where they believe their lots will be bettered than taken up a monthly paid job with low incentive. The majority of the research respondents in this study were married. The average educational attainment of the research respondents in this study was postgraduate level. This finding was in contrast with previous research studies which reported in their respective studies that the majority of their respondents had secondary and college education $[26,27]$.

\section{Participants' awareness of stroke}

Interestingly, the current study shows that there was a general prevalence of poor awareness of stroke risk factors among the population of non-teaching staff in Nnamdi Azikiwe University. It also shows a weak level of relationship between the awareness of stroke risk factors and the level of educational attainment among the population of non-teaching staff members of Nnamdi Azikiwe University, Nnewi Campus. This was deduced from the ranking of awareness of stroke risk factors among research respondents in terms of good (28.7\%), fair (31\%), and poor (40.3\%) as was shown in Table 5. These 
research findings run counter-intuitive to the often generally expected and held view that having a higher education level was always associated with a greater degree of knowledge of warning signs of stroke as concluded by Soto-Cámara et al. [28] using a cross-sectional study involving all stroke patients which were admitted consecutively at the Burgos University Hospital in Spain.

In the current study, females with a postgraduate level of education and working as senior non-teaching staff were likely to have a better awareness of stroke risk factors. This was in contrast to previous studies where good predictors of good knowledge were male gender, higher educational level, parents who had a stroke in the past, and having multiple risk factors of stroke [29, 30]. Another finding of this study that seemed intuitively inconsistent was also the fact that most people who have a history of stroke in their family lineage were more ignorant of stroke risk factors. This was a very odd research finding of this study as it was expected that those who knew that they were more at the risk of having a stroke due to their family history would have ordinarily become more aware of stroke risk factors. Reeves et al. [25] arrived at the same conclusion after carrying out a survey involving over 2500 adults using multiple logistic regression to support the counter-intuitive findings of this research study. The researchers tried to find an explanation for these seemingly odd research findings in this study and a rationale to justify this counterintuitive behavior among the research respondents. Of all the factors which were examined, it became clear that a plausible explanation for these anomalies could be the fact that more than half $(52.7 \%)$ of the sample population were young adults within the age bracket of 18 and 40. Previous study finding shows that young adults were more likely to focus more on raising a family and seeking a better financial future than to be concerned about their general health condition [31]. Also, the increasing and widening social inequality in the country could also be another crucial consideration. Stack et al. [31] who studied the effect of socio-economic position on the knowledge of risk factors and warning signs of stroke in the World Health Organization (WHO) European region came to the harsh conclusion that a better knowledge of stroke risk factors and warning signs is associated with a higher socio-economic position (SEP) and thus recommended that public health campaigns and educational interventions aiming to increase stroke knowledge should be targeted at people with lower SEP. This conclusion lent credence to the researchers' assumption of a widespread and widening socio-economic inequality among young adults in the Nigerian society as being a justification and an explanation for the odd and counter-intuitive research findings by this study.

\section{Participants' awareness of the individual risk factors of stroke}

There seems to be a consensus between both the male and female research respondents that high blood pressure, stress, high cholesterol level, and lack of exercise were the leading stroke risk factors. The majority of both the male and female respondents agree that sickle cell anemia and coronary heart disease were not among the major stroke risk factors. The majority of the respondents in the current study have highlighted high blood pressure to be the commonest risk factor of stroke, and this was found to be similarly reported in previous studies [32-34].

When stroke risk factors relating to lifestyle choices across the genders were examined, more men surprisingly identified cigarette smoking as a stroke risk factor. As expected, most females did not recognize obesity as a stroke risk factor, and the majority of the males refused to acknowledge alcohol consumption as a stroke risk factor. One of the reasons for this may be subjective due to the fact that most of the male respondents were alcohol drinkers and females not so physically active in terms of exercise, so they did not want to hurt their feelings by acknowledging them as risk factors. Most of the findings of this research study in this regard tended to agree with the conclusion arrived at by the study carried out by Müller-Nordhorn et al. using a population-based survey involving sending questionnaires randomly to selected residents in Berlin, where they found that men were significantly more likely to name smoking, physical inactivity, alcohol consumption, poor diet/nutrition, age, or stress as a risk factor, whereas women were more likely to name hypertension, obesity, hypercholesterolemia, diabetes, or heart disease as a risk factor [35].

\section{Source of information on stroke among the participants}

In terms of assessing the respondents' preferred sources of information regarding stroke risk factors, the study found health staff, doctors, and nurses to be the preferred source of information among the research respondents at $76.7 \%$. Health education material, posters, and brochures were the next preferred sources of information among the respondents at $24 \%$, while books, television and radio, newspaper and magazines, and family members were the least preferred sources of information at $11.6 \%$, $7.8 \%, 5.4 \%$, and $1.6 \%$, respectively. This finding seems to be in contrast with the findings of Nakibuuka et al. [36] who found that information from family/relatives was the commonest source of information chosen by most of the participants. Also, Wafa et al. [37] found that most participants preferred encountering a patient with a stroke which was mostly a family member as their most preferred source of information. Although interpersonal 
contacts and the use of TV/radio have been a good means of disseminating medical information, better and effective communication between patients and clinicians may increase the awareness and knowledge of stroke, how to reduce its risk factors, and what timely interventions to take when it occurs [37]. According to most studies, the main source of information on stroke was gotten through mass media, having contact with someone who had a stroke, or through school [38].

\section{Association between awareness of stroke risk factors and the demographics of participants}

There was no significant association between the level of awareness of stroke risk factors and participants' gender, marital status, age, educational level, and non-teaching staff position. These findings were significant to the extent that it shows that the level of awareness of stroke risk factors cannot be said to be influenced by any of the demographic variables examined in the current study, though, among the participants, females with postgraduate education was found to be more likely to be aware of the stroke risk factors than their male counterparts. However, the research findings by Olorukooba et al. revealed an association between the educational level and gender in their study [39]. Ordinarily, the researchers would have held an opinion that the population of the study would have shown a strong association between the demographic variables and the knowledge of the risk factors of stroke, but the current findings from this study have proved otherwise.

\section{Implication of the study}

The implication of this study is that the knowledge of the risk factors for an ailment will provoke a desire for the individual to manage their risks to prevent the event from occurring [40, 41]. Generally, public baseline knowledge of stroke risk factors is low [42], and this has been one of the major findings of this study in the sample population. The most effective treatment of stroke is prevention, and a major step in stroke prevention is knowledge of the risk factors and learning how to reduce them [43]. There is strong evidence that modifying the risk factors for stroke will greatly reduce the incidence of stroke by as much as $80 \%[44,45]$, and so every occurrence of stroke can thus be considered as a failure of primary healthcare [46].

\section{Conclusion}

Stroke awareness was found to be poor among the respondents with the highest risk of stroke despite their high literacy level. The female respondents, with a postgraduate level of education and working as senior nonteaching staff, were likely to have a better awareness of stroke risk factors than their male colleagues. This lowlevel awareness might be attributed to the low level of awareness creation on the causes and prevention of stroke by various governmental and non-governmental agencies to this population studied. Also, it might indicate that majority of non-teaching staff do not quest for health-related knowledge in their private capacity.

\section{Limitation of study}

The major limitation of this study is the number of respondents that completed the questionnaire out of the 200 sampled population.

\section{Recommendation}

There is an urgent need to increase stroke awareness campaigns in the higher institution of learning especially among non-academic staff members. The risk factors of stroke should be taught to all individuals whether they have the risks or not. This may help them change some of their health actions and thus prevent the development of stroke. Health regulatory bodies, hospital administrators, and unit supervisors/heads should ensure that patient education should be emphasized in all clinician-patient interaction processes, particularly for patients with risk factors for stroke.

\section{Abbreviations}

CVA: Cerebrovascular accident; SPSS: Statistical Package for Social Sciences; IBM: International Business Machine Cooperation; WHO: World Health Organization; SEP: Socio-economic position; TV: Television.

\section{Acknowledgements}

We, hereby, appreciate all non-teaching staff of Nnamdi Azikiwe University, Nnewi Campus for participating in the study, and the two research assistants for their assistance in distributing and retrieving the questionnaires.

\section{Authors' contributions}

UPO and FNU were responsible for the conceptualization/design. MJO, ECO, and JOU did the acquisition and analysis. ESI, SMM, and SMM did the interpretation of the data. UPO, KUA, UNA, and CAN were responsible for the drafting and revision. All authors have read and approved the final manuscript.

\section{Funding}

The study was funded by the researchers.

Availability of data and materials

The authors will make the data available when a cogent request is made.

\section{Declarations}

Ethics approval and consent to participate

Ethics approval was obtained from the Ethics Committee of Faculty of Health Sciences and Technology, Nnamdi Azikiwe University, Nnewi Campus. The reference number is [/NAU/FHST/2021/MRH126]. Informed consent to participate was sought and obtained from the participants. Ethics approval was obtained from the Ethics Committee of Faculty of Health Sciences and Technology, Nnamdi Azikiwe University, Nnewi campus. The reference number is / NAU/FHST/2021/MRH126. Informed consent to participate was sought and obtained from the participant.

\section{Competing interests}

The authors declare that they have no competing interests. 


\section{Author details}

${ }^{1}$ Department of Medical Rehabilitation, Faculty of Health Sciences and Technology, Nnamdi Azikiwe University, Awka, Nigeria. ${ }^{2}$ Department of Medical Rehabilitation, University of Nigeria, Nsukka, Nigeria.

\section{Received: 13 August 2021 Accepted: 19 October 2021} Published online: 23 November 2021

\section{References}

1. Better Health. Stroke risk factors. 2010 Available from: http://www.better\%20health\%202015risk\%20factors.htm.

2. Owolabi MO, Akarolo-Anthony S, Akinyemi R, Arnett D, Gebregziabber M, Jenkins $C$, et al. The burden of stroke in Africa: a glance at the present and a glimpse into the future. Cardiovasc J Afr. 2015;26(2 suppl 1):S27-8.

3. National Institute of Neurological Disorders and Stroke (2020). Stroke: hope through research.

4. Walker R, Whiting D, Unwin N, Mugusi F, Swai M, Aris E, et al. Stroke incidence in rural and urban Tanzania: a prospective, community-based study. Lancet Neurol. 2010;9:786-92.

5. Ezejimofor MC, Uthman OA, Maduka O, Ezeabasili AC, Onwuchekwa AC, Ezejimofor BC, et al. Stroke survivors in Nigeria: a door-to-door prevalence survey from the Niger Delta region. J Neurol Sci. 2017:372:262-9.

6. Agyemang C, Attah-Adjepong G, Owusu-Dapo E, Aikins ADJ, Addo J, Edusei A, et al. Stroke in Ashanti region of Ghana. Ghana Med J. 2012;46:12-7.

7. Danesi M, Okubadejo N, Ojini F. Incidence of stroke in an urban mixed-income community in Lagos, Nigeria. Neuroepidemiology. 2007;28:216-23.

8. Ogun SA, Ojini Fl, Ogungbe B, Kolapo KO, Danesi MA. Stroke in south west. A 10-year review. Stroke 2005;36(6):1120-1122.

9. Wahab KW, Okokhere OP, Ugheoke AJ, Oziegbe O, Asalu AF, Salami TA. Awareness of warning signs among suburban Nigerians at high risk for stroke is poor: a cross-sectional study. 2008 Available from: http//www. biomedical.com/147-22377/8/18.

10. Ogungbo B, Ogun SA, Ushewokunze AD, Rodgers H, Walker R. How can we improve the management of stroke in Nigeria, Africa? Afr J Neurol Sci. 2005;24(2):9-19.

11. Komolafe MA, Ogunlade O, Komolafe G. Stroke mortality in a teaching hospital in south-western. Nigerian Afr J Neurol Sci. 2006;22(3-5):281-91.

12. Komolafe MA, Ogunlade O, Komolafe EO. Stroke mortality in a teaching hospital in. South Western Nigeria Tropical Doctor. 2007;37(3):186-8.

13. Akinyemi OR. Global epidemiology of stroke with special reference to Sub-Saharan Africa. 2016 https://www.ean.org/fileadmin/user_upload/ Akinyemi_R Stroke_Epidemiology.pdf.

14. Alkadry MG, Wilson C, Nicholson D. Stroke awareness among rural residents: the case of West Virginia. Soc Work Health Care. 2005;42:73-92.

15. Al Shafaee AM, Ganguly SS, Al Asmi AR. Perception of stroke and knowledge of potential risk factors among Omani patients at increased risk for stroke. BMC Neurol. 2006;38(6):1471-2377.

16. Hickey A, Hanlon AO, McGee H, Donnellan C. Stroke awareness in the general population: knowledge of stroke risk factors and warning signs in older adults. BMC Geriatr. 2009;35(9):1471-238

17. Stroebele N, Muller-Riemenschneider F, Nolte $\mathrm{CH}$, Muller-Nordhorn J, Bockelbrink A, Willich SN. Knowledge of risk factors and warning signs of stroke: a systematic review from a gender perspective. Int J Stroke. 2011;6(1):60-6

18. Nicol MB, Thrift AG. Knowledge of risk factors and warning signs of stroke. J Vascular Health Risk Manag. 2005;192:137-47.

19. Yusuf $O B$, Adebowale AS, Fagbamigbe AF, Bamboye EA, Oyediran ABOO. Profile of academic and senior non-teaching staff in a Nigerian university. Int J Educ Administration Policy Stud. 2010;2(7):92-8.

20. Hickey A, O'Hanlon A, McGee H, et al. Stroke awareness in the general population: knowledge of stroke risk factors and warning signs in older adults. BMC Geriatr. 2009;9:35 https://doi.org/10.1186/ 1471-2318-9-35.

21. Kamran S, Bener AB, Deleu D, Khoja W, Jumma M, Al Shubali A, et al. The level of awareness of stroke risk factors and symptoms in the Gulf Cooperation Council: Gulf Cooperation Council stroke awareness study. Neuroepidemiology. 2007;29:235-42.
22. Blades LL, Oser CS, Dietrich DW, Okon NJ, Rodriguez DV, Burnett AM et al. Rural community knowledge of stroke warning signs and risk factors. J Preventive Chronic Dis. 2005;2(2). http://www.cdc.gov/pcd/issues/2005/ apr/04_0095.htm

23. Greenlund KJ, Neff LJ, Zheng ZJ, et al. Low public recognition of major stroke symptoms. Am J Prev Med. 2003;25:315-9.

24. Travis LH, Flemming KD, Brown RD Jr, Meissner I, McClelland RI, Weigand $\mathrm{SD}$. Awareness of stroke risk factors, symptoms, and treatment is poor in people at the highest risk. J Stroke Cerebrovasc Dis. 2003;2(5):221-7.

25. Reeves MJ, Hogan JG, Rafferty AP. Knowledge of stroke risk factors and warning signs among Michigan adults. Neurology. 2002;59:1547-52.

26. Pandian JD, Kalra G, Jaison A, Deepak SS, Shamsher S, Lincoln DJ, et al. Public awareness of warning symptoms, risk factors, and treatment of stroke in North-West India. J Am Heart Assoc (Stroke). 2005:36:644-8.

27. Yoon SS, Heller RF, Levi C, Wiggers J. Knowledge and perception about stroke among an Australian urban population. BMC Public Health. 2001;1:14 https://bmcpublichealth.biomedcentral.com/articles/10.1186/ 1471-2458-1-14.

28. Soto-Cámara R, González-Bernal JJ, González-Santos J, Aguilar-Parra JM, Trigueros R, López-Liria R. Knowledge on signs and risk factors in stroke patients. J Clin Med. 2020;9(8):2557.

29. Adebimpe WO. Knowledge and risk factors for stroke among undergraduates in Southwestern Nigeria. Marshall J Med. 2018;4(3): Article 4.

30. Ehidiamen OF, Ehinwenma OJ. Awareness of stroke risk factors and warning symptoms amongst hypertensive patients in Benin City. Ann Med Health Sci Res. 2018;8(1):40-4

31. Stack K, Robertson W, Blackburn C. Does socioeconomic position affect knowledge of the risk factors and warning signs of stroke in the WHO European region? A systematic literature review. BMC Public Health 2020;20:1473

32. Obembe AO, Olaogun MO, Bamikole AA, Komolafe MA, Odetunde MO Awareness of risk factors and warning signs of stroke in a Nigerian university. J Stroke Cerebrovasc Dis. 2014;23(4):749-58.

33. Hamdy H, Abdet-Monem A, Emara T, Moustafa R, Abdel-Bar A, Abuzeld S. Knowledge and attitudes towards stroke among workers in two university hospitals. Egypt J Neurol Psychol Neurosurg. 2013;50:49-54.

34. Gutierrez-Jimenez E, Gongora-Rivera F, Martinez HR, Escamilla-Garza $J M$, Villarreal HJ. Knowledge of ischemic stroke risk factors and warning signs after a health education program by medical students. Stroke. 2011:42:897-901.

35. Müller-Nordhorn J, Nolte CH, Rossnagel K, Jungehülsing GJ, Reich A, Roll S, Villringer A, Willich SN. Knowledge about risk factors for stroke, a population-based survey. American Heart Association, Inc. 2006 Retrieved June $25^{\text {th }} 2021$ from http://strokeahajournal/org/ogi/content/abstract.

36. Nakibuuka J, Sajatovic M, Katabira E, Ddumba E, Byakika-Tusime J, Furkan AJ. Knowledge and perception of stroke: a population-based survey in Uganda. ISRN Stroke. 2014;2014:309/06. https://doi.org/10.1155/2014/ 309/06.

37. Wafa HA, Wolfe C, Rudd A, Wang Y. Long-term trends in incidence and risk factors for ischaemic stroke subtypes: prospective population study of the South London Stroke Register. PLoS Med. 2018;15(10):e1002669. https//doi.org/10.1371/journal.pmed.1002669

38. Naglaa ES, Hadeer AG, Sherine E. Awareness of stroke in adults and pediatrics among Fayoum University Hospital workers and medical students. Egypt J Neurol Psychiat Neurosurg. 2011;48(3):235-40.

39. Olorukooba AA, Mohammed Y, Yahaya SS, Amadu L, Ibrahim JM, OnojaAlexander MO. Awareness of stroke and knowledge of its risk factors among respondents in Shika community, Kaduna State, Nigeria. Arch of Med Surg. 2016:3:30-4.

40. Boden-Albala B, Carman H, Moran M, Doyle M, Paik MC. Perception of recurrent stroke risk among Black, White and Hispanic ischemic stroke and transient ischemic attack survivors: the SWIFT Study. Neuroepidemiology. 2011;37(2):83-7.

41. Eshah NF. Knowledge of stroke and cerebrovascular risk factors among Jordanian adults. J Neurosci Nurs. 2013;45(5):13-9.

42. Biederman DJ, Sienkiewicz HC, Bibeau DL, Chase CM, Spann LI, Romanchuck J, et al. Ethnic and racial differences of baseline stroke knowledge in a stroke belt community. Health Promot Pract. 2012;13(1):63-70.

43. Madubuko AN. Stroke risk factor knowledge, attitude, prevention practices, and stroke. 2018 Available from: https. [Accessed on the $15^{\text {th }}$ March 2020]. 
44. Howard G, Cushmann M, Kissela BM, Kleindorfer DO, McClure LA, Saffoord MM, et al. Traditional risk factors as the underlying cause of racial disparities in stroke: lessons from the half-full (empty?) glass. Stroke. 2011:42(12):3369-75.

45. Meschia JF, Bushnell C, Boden-Albala B, Braun LT, Bravado DM, Chaturvedi $S$, et al. Guidelines for the primary prevention of stroke: a statement for healthcare professionals from the American Heart Association/American Stroke Association. Stroke. 2014;45(12):3754-832.

46. Lackland DT, Roccella EJ, Deutsch AF, Fornage M, George MG, Howard G, et al. Factors influencing the decline in stroke mortality a statement from the American Heart Association/American Stroke Association on behalf of the American Heart Association Stroke Council, Council on Cardiovascular and Stroke Nursing, Council on Quality of Care and Outcomes Research, and Council on Functional Genomics and Translational Biology. Stroke. 2014;45(1):315-53.

\section{Publisher's Note}

Springer Nature remains neutral with regard to jurisdictional claims in published maps and institutional affiliations.

\section{Submit your manuscript to a SpringerOpen ${ }^{\circ}$ journal and benefit from:}

- Convenient online submission

- Rigorous peer review

- Open access: articles freely available online

- High visibility within the field

- Retaining the copyright to your article

Submit your next manuscript at $\boldsymbol{\nabla}$ springeropen.com 